Original Article

\title{
A VALIDATED STABILITY INDICATING RP-HPLC METHOD FOR ESTIMATION OF TOLFENAMIC ACID IN PRESENCE OF ITS PHARMACOPOEIAL IMPURITIES
}

\author{
ADISON FERNANDES ${ }^{*}$, SANJAY PAI P. N. ${ }^{2}$ \\ 1Department of Pharmaceutical Analysis, Goa College of Pharmacy, Goa University, Goa, India 403001, 2Department of Pharmaceutical \\ Chemistry, Goa College of Pharmacy, Goa University, Goa, India 403001 \\ Email: adison.fernandes@gmail.com
}

Received: 18 Jun 2019, Revised and Accepted: 06 Aug 2019

\section{ABSTRACT}

Objective: The proposed research work was conducted to develop a single reverse-phase high-performance chromatography (RP-HPLC) method capable of separating two Pharmacopoeial related impurities as well as degradation product of Tolfenamic acid (TA). The drug was subjected to various stress conditions recommended under ICH Q1A (R2) guidelines.

Methods: The desired separation of two Pharmacopoeial impurities and one degradant generated under oxidative stress was carried out using Sunfire ODS C-18 $(250 \times 4.6 \mathrm{~mm}, 5 \mu \mathrm{m})$ column maintained at $40^{\circ} \mathrm{C}$. Isocratic elution was carried out using acetonitrile and ammonium dihydrogen orthophosphate buffer $(10 \mathrm{mmol}, \mathrm{pH} 2.5)$ in the ratio of $80: 20 \mathrm{v} / \mathrm{v}$. The detection was carried out at $205 \mathrm{~nm}$ using flow rate of $1 \mathrm{ml} / \mathrm{min}$. The developed method was validated as per ICH Q2 (R1) guidelines for specificity, linearity, accuracy, precision, Limit of detection (LOD), Limit of Quantification (LOQ) and robustness.

Results: Linearity response of TA was found at a concentration range of $10-100 \mu \mathrm{g} / \mathrm{ml}$, with a correlation coefficient of 0.9987 . The Pharmacopoeial impurity A and impurity B showed linearity results at concentration of $0.1-1 \mu \mathrm{g} / \mathrm{ml}$, with correlation coefficient of 0.9984 for Impurity A and 0.9989 for Impurity B. The \% recovery during accuracy studies for TA and the two impurities were within the acceptance range of 95-105\%. LOD and LOQ for TA were found to be $4.561 \mu \mathrm{g} / \mathrm{ml}$ and $133.771 \mu \mathrm{g} / \mathrm{ml}$ respectively. For impurity A, LOD and LOQ were found to be $0.035 \mu \mathrm{g} / \mathrm{ml} \mathrm{and} 0.106 \mu \mathrm{g} / \mathrm{ml}$ and for Impurity B, LOD and LOQ were $0.042 \mu \mathrm{g} / \mathrm{ml}$ and $0.128 \mu \mathrm{g} / \mathrm{ml}$. With slight variation of organic phase in mobile phase and flow rate the method exhibited good robustness. Under forced degradation studies the drug was found stable under hydrolytic, photolytic and thermal stress conditions, but was found susceptible for degradation under oxidative stress with appearance of a degradant peak. From on the RRT values of Pharmacopoeial impurities and the formed degradant it was inferred that the developed method is selective for the drug in the presence of impurities or degradants.

Conclusion: The developed stability-indicating method is found to be simple, rapid, accurate, precise and robust as compared to other proposed methods while determining TA in presence of its Pharmacopoeial impurities and degradation products. Hence the developed method can be used for analysis of stability samples of TA in presence of its related impurities.

Keywords: Tolfenamic acid, Related impurities, RP-HPLC, ICH Q2 (R1) guidelines, Stability indicating

(C) 2019 The Authors. Published by Innovare Academic Sciences Pvt Ltd. This is an open access article under the CC BY license (http://creativecommons.org/licenses/by/4.0/] DOI: http://dx.doi.org/10.22159/ijap.2019v11i5.34606

\section{INTRODUCTION}

Tolfenamic acid (TA) is 2-[(3-chloro-2-methylphenyl) amino] benzoic acid (fig. 1) [1]. British pharmacopoeia lists three impurities in the monograph of TA (fig. 1) [2]. TA belongs to the class of fenamates of the nonsteroidal anti-inflammatory drug (NSAID) and is used for treatment of inflammation and pain in humans as well as animals. Mostly used for the remedy of acute migraine attacks and for the relief of pain in conditions such as osteoarthritis, dysmenorrhea and rheumatoid arthritis [3-4]. TA has gained high popularity recently for its anticancer activity against different types of cancer [5-8]. The concentration of all the related substances associated with drug as per ICH guidelines must be less than $0.2 \%$ of the concentration of drug except for isopropyl ethers and monoester, whereas the limit should not exceed $0.2 \%$ at different storage concentrations [9].

Study on TA by various analytical methods has been reported in the literature. Few of them include titrimetry [10], spectrophotometry [11], spectrofluorimetry [12] and reversed phase high-performance liquid chromatography (RP-HPLC) methods [13-20]. A literature highlighted the separation of two related impurities of TA i.e. 2chlorobenzoic acid (CBA) and 3-chloro-2-methylaniline (CMA) by HPLC and TLC densitometric method [21] without commenting on the stability-indicating potential of the method. Whereas minimum literature, till date is an available wherein stability-indicating method for TA by RP HPLC in presence of its related impurities, has been reported.

Hence the current work was undertaken to develop and validate a RP-HPLC method for the estimation of TA in the presence of its two
Pharmacopoeial impurities i.e. Impurity A (CBA) and Impurity B (CMA) and also perform as a stability-indicating method. The drug was subjected to various stress conditions of hydrolysis, oxidation, photolysis and thermal as per ICH guidelines [22]. The developed method is the first report of its kind which could be applied for effective separation of TA from its Pharmacopoeial impurities and other degradants formed under stress conditions.<smiles>CC1=C(Cl)CCC=C1N</smiles>

C<smiles>O=C(O)c1ccccc1Cl</smiles>

B<smiles>Cc1c(Cl)ccc2c(=O)c3ccccc3[nH]c12</smiles>

D
Fig. 1: A) Chemical structure of Tolfenamic acid, B) Chemical structure of 2-chlorobenzoic acid (Impurity A), C) Chemical structure of 3-chloro-2-methyl aniline (Impurity B) and D)

Chemical structure of 3-chloro-4-methyl-9-oxo-9, 10dihydropyridine (Impurity C) 


\section{MATERIALS AND METHODS}

\section{Chemicals}

Tolfenamic acid was obtained as a gift sample from Pure and Cure Healthcare Ltd (Uttarakhand, India). Impurities were purchased from Sigma-Aldrich Co., St. Louis, MO, USA. The Chemicals used in this work include, Acetonitrile (HPLC grade-Rankem, India),whereas ammonium dihydrogen orthophosphate (AR), orthophosphoric acid (AR), ammonia solution (AR), Hydrochloric acid(HCl)(AR), Sodium hydroxide $(\mathrm{NaOH})(\mathrm{AR})$, and hydrogen peroxide $(10 \%, \mathrm{v} / \mathrm{v})(\mathrm{AR})$, were procured from Merck, India. HPLC grade water used in the study was obtained from Bio-age water purification system. All the solvents and sample solutions were filtered through $0.45 \mu \mathrm{m}$ membrane filter before injecting into the HPLC system.

\section{HPLC Instrument and chromatographic conditions}

In the current research work, Jasco LC-4000 series HPLC system consisting of a quaternary solvent delivery system, an on-line degasser, an auto-sampler, a column temperature controller and a diode array detector was used. System control and data analysis were processed with Jasco Chrom NAV software. Other instruments utilized in the study include Bath sonicator (Citizon Ultrasonic cleaner); Digital Balance (Wensar Digital Electronic Balance) and $\mathrm{pH}$ meter (Labtronics, LT-10). Optimum separation and estimation were achieved on Sunfire ODS C18 column $(250 \times 4.6 \mathrm{~mm}, 5 \mu \mathrm{m})$ from Waters. The mobile phase used for the study involved acetonitrile and $10 \mathrm{mmol}$ ammonium dihydrogen ortho phosphate buffer ( $\mathrm{pH}$ adjusted to 2.5 with o-phosphoric acid) in the ratio of $80: 20 \mathrm{v} / \mathrm{v}$, with flow rate of $1 \mathrm{ml} / \mathrm{min}$. Studies were performed with column temperature at 40 ${ }^{\circ} \mathrm{C}$, and injecting volume as $10 \mu \mathrm{l}$ with detection wavelength of $205 \mathrm{~nm}$.

\section{Buffer solution}

10 mmol ammonium dihydrogen ortho phosphate buffer was prepared by dissolving $1.15 \mathrm{~g}$ of ammonium dihydrogen ortho phosphate in HPLC water and the volume was made up to the mark in a standard 1 litre volumetric flask. The $\mathrm{pH}$ was adjusted to 2.5 using ortho phosphoric acid solution. The prepared buffer solution was filtered through $0.45 \mu$ membrane filter.

\section{Stock standard solutions $(1,000 \mu \mathrm{g} / \mathrm{ml})$}

Stock standard solutions of TA, CBA, and CMA were prepared by weighing separately and accurately $10 \mathrm{mg}$ of pure powder of each into three separate $10 \mathrm{ml}$ standard volumetric flasks. Sufficient quantity of acetonitrile was added in all the volumetric flasks and sonicated for $15 \mathrm{~min}$ to dissolve the substance. The final volumes were made to the mark with acetonitrile and mixed well.

\section{Working standard solutions $(100 \mu \mathrm{g} / \mathrm{ml})$}

Working standard solutions of CBA and CMA were prepared by accurately transferring $1 \mathrm{ml}$ each of CBA and CMA from their respective stock standard solutions $(1,000 \mu \mathrm{g} / \mathrm{ml})$ into 2 separate 10 $\mathrm{ml}$ volumetric flasks. Volume up to the mark was made with acetonitrile to get $100 \mu \mathrm{g} / \mathrm{ml}$ working standard of each component.

\section{Selection of the detection wavelength for the method}

Spectra scan of the three components in the range of $190 \mathrm{~nm}$ to 400 $\mathrm{nm}$ was run. From the Overlays of the spectra's the wavelength that showed sufficient absorbance of all the components was selected for the study. Thus Wavelength of $205 \mathrm{~nm}$ was selected as the detection wavelength for the current method.

\section{Method validation}

The developed RP HPLC method for separation of specified impurities and possible degradants obtained of TA was validated as per ICH guidelines Q2 (R1) [23].

\section{Specificity}

The specificity of the method was evaluated by application of the developed method to a mixture containing $10 \mu \mathrm{g} / \mathrm{ml}$ concentration of $\mathrm{TA}$, and $1 \mu \mathrm{g} / \mathrm{ml}$ of CBA and CMA. Specificity of the method was also checked for the samples of TA subjected to various forced/stressed conditions as per ICH guideline. Specificity of the method was confirmed by calculating system suitability testing parameters such as resolution, peak asymmetry, and no of theoretical plates, for the separated chromatographic peaks and the formed degradants peaks.

\section{Linearity and range}

Fixed volumes equivalent to $10-100 \mu \mathrm{g} / \mathrm{ml}$ of $\mathrm{TA}$ were separately transferred from the stock standard solution of TA $(1,000 \mu \mathrm{g} / \mathrm{ml})$ into 10 $\mathrm{ml}$ volumetric flask and the volume was made up to the mark with the mobile phase. For impurities, volumes equivalent to $0.1-1 \mu \mathrm{g} / \mathrm{ml}$ of CBA, and CMA were separately transferred from their respective working standard solutions $(100 \mu \mathrm{g} / \mathrm{ml})$ into $10 \mathrm{ml}$ volumetric flasks. The volume was made to the mark with the mobile phase. Six $10 \mu \mathrm{l}$ injections were given of each concentration. The calibration curves were plotted and the regression parameters were obtained.

\section{Precision}

Intraday repeatability and interday repeatability of the method was evaluated by analyzing $40 \mu \mathrm{g} / \mathrm{ml}$ concentration of and $0.4 \mu \mathrm{g} / \mathrm{ml}$ concentrations of each impurity. Interday precision was done on two successive days using the same procedure stated under chromatographic conditions. The percentage relative standard deviation (\%RSD) values were then calculated.

\section{Accuracy}

Accuracy of the developed method was determined by recovery studies using standard addition method. The percentage recovery studies of TA, CBA, and CMA was carried out in triplicate at 3 different levels of $80 \%, 100 \%, 120 \%$.

\section{Sensitivity}

The sensitivity of the developed method was determined by calculating LOD and LOQ for TA and its two impurities. LOD and LOQ were calculated for TA and its two impurities based on the Standard deviation of the Response and the Slope as mentioned below.

LOD $=3.3 \mathrm{X}$ Standard deviation of the response/Slope of the calibration curve

$\mathrm{LOQ}=10 \mathrm{X}$ Standard deviation of the response/Slope of the calibration curve

\section{Robustness}

The robustness of the method was done to check the effect of small deliberate changes in the chromatographic conditions. Changes in the flow rate of the mobile phase $( \pm 0.2$ unit) and the proportion of organic phase in the mobile phase $( \pm 2$ units) on the developed method were studied. The system suitability parameters where checked for verifying the robustness of the method.

\section{Forced degradation studies}

To assess the stability-indicating power and specificity of the method, forced degradation studies were performed. Forced degradation of drug in acidic and basic medium was carried in $1 \mathrm{~N}$ $\mathrm{HCl}$ and $1 \mathrm{~N} \mathrm{NaOH}$ respectively at $70{ }^{\circ} \mathrm{C}$ for a period of $6 \mathrm{~h}$. The stressed samples were first cooled to room temperature, followed by neutralization and finally the volume was made up to mark by mobile phase. Degradation of drug in neutral medium was done by treating the drug with water for a period of $6 \mathrm{~h}$ at $70^{\circ} \mathrm{C}$.

Oxidative degradation of the drug was carried by subjecting the drug to react with $10 \% \mathrm{H}_{2} \mathrm{O}_{2}$ solution for a period of $6 \mathrm{~d}$. Photolysis of the drug was carried by exposing the drug to direct sunlight for $4 \mathrm{~d}$, whereas for thermal degradation the drug was heated in an oven at $80^{\circ} \mathrm{C}$ for $9 \mathrm{~h}$. The stressed samples obtained in neutral and thermal stress conditions were cooled to room temperature and diluted with mobile phase. The oxidative and photolytic stressed samples were diluted with mobile phase. The samples of forced degradation studies were diluted with mobile phase to give a final concentration of $10 \mu \mathrm{g} / \mathrm{ml}$ before injecting in the system.

\section{RESULTS AND DISCUSSION}

\section{Chromatographic separation}

The method involved separation of TA from its two impurities and other possible degradants under stress conditions. For carrying out 
efficient separation effect of various $\mathrm{pH}$ of the buffer along with the various composition of the mobile phase was studied. The mobile phase selected was acetonitrile as organic phase and ammonium dihydrogen ortho phosphate as buffer $(10 \mathrm{mmol})$. Various trials were carried out with $\mathrm{pH}$ of buffer ranging from 2.5 to 6.5. Optimum separation of the drug from its specified impurities was obtained when the $\mathrm{pH}$ of the buffer was fixed at 2.5 and the composition of acetonitrile and buffer was in the ratio of $80: 20 \% \mathrm{v} / \mathrm{v}$ under isocratic elution. The following separation was performed on the available Sunfire ODS C-18 (250 x $4.6 \mathrm{~mm}, 5 \mu \mathrm{m})$ column maintained at $40{ }^{\circ} \mathrm{C}$. The detection was carried out at $205 \mathrm{~nm}$ using flow rate of 1 $\mathrm{ml} / \mathrm{min}$. The optimized chromatographic conditions used for the developed method are different from the available method [21] as shown in table 1.

Table 1: Optimized chromatographic conditions of the proposed RP HPLC method

\begin{tabular}{|c|c|}
\hline Mobile phase & $\begin{array}{l}\text { Mixture of acetonitrile and } 10 \text { mmol ammonium dihydrogen orthophosphate buffer (pH adjusted to } 2.5 \text { with } \\
\text { orthophosphoric acid) in the ratio of } 80: 20 \% \mathrm{v} / \mathrm{v} \text {. }\end{array}$ \\
\hline Column & Sunfire ODS C18 (4.6 x $250 \mathrm{~mm}, 5 \mu \mathrm{m})$ column \\
\hline Injection Volume & $10 \mu \mathrm{l}$ \\
\hline Flow Rate & $1 \mathrm{ml} / \mathrm{min}$ \\
\hline Column oven temperature & $40^{\circ} \mathrm{C}$ \\
\hline Detection wavelength & $205 \mathrm{~nm}$ \\
\hline
\end{tabular}

\section{System suitability}

The developed method at the optimized chromatographic conditions efficiently resolved TA from its 2 specified impurities as shown by a representative chromatogram in fig. 2. The concentration of TA and the two impurities used for the system suitability is $50 \mu \mathrm{g} / \mathrm{ml}$ and $5 \mu \mathrm{g} / \mathrm{ml}$ respectively. The system suitabilty parameters of all the three components are listed in table 2 .

Table 2: System suitability parameters of the proposed RP HPLC method

\begin{tabular}{|c|c|c|c|c|c|c|c|}
\hline S. No. & Components & Rt & RRT & Area & Resolution & Peak asymmetry & Theoretical plate \\
\hline 1 & Tolfenamic acid $(50 \mu \mathrm{g} / \mathrm{ml})$ & 6.650 & - & 3218433 & NA & 1.098 & 14400 \\
\hline 2 & 2-Chlorobenzoic acid & 3.017 & 0.453 & 533577 & 7.504 & 1.213 & 7515 \\
\hline 3 & 3-chloro-2-methylaniline & 4.108 & 0.617 & 829977 & 13.621 & 1.069 & 11607 \\
\hline
\end{tabular}

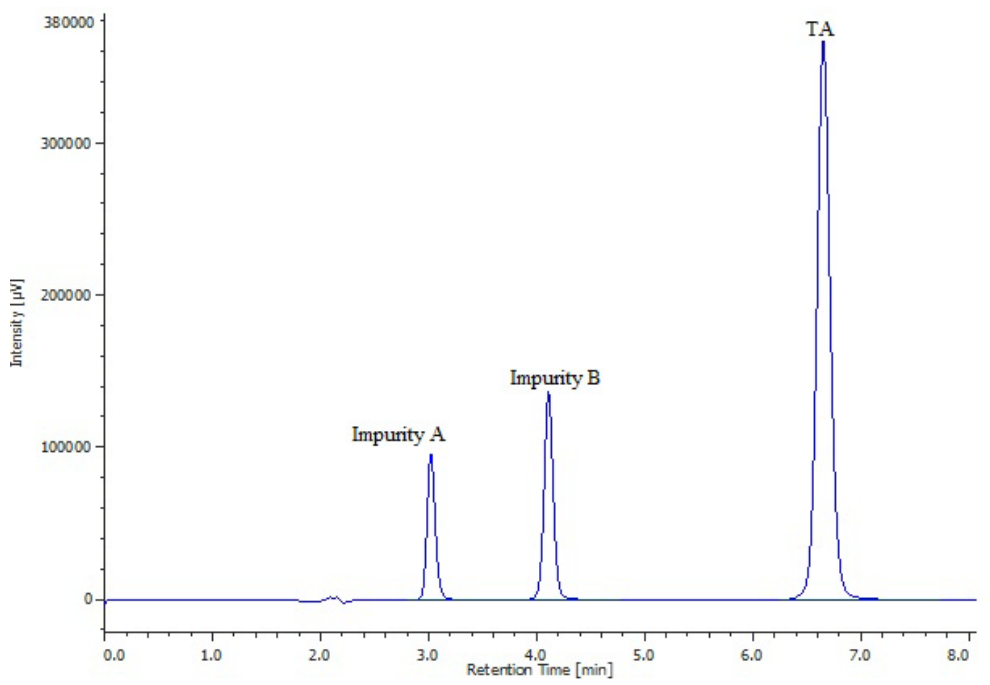

Fig. 2: Optimized chromatogram showing separation of tolfenamic acid (TA) from the impurities and also from each other

The obtained chromatogram showed tailing factor of less than 1.3 for all the peaks, a resolution of more than 2 for CBA and DMA with respect to TA. The number of theoretical plates, tailing factor and the resolution for the three components were within the limits of acceptance criteria (reference) specified in ICH guidelines.

\section{Specificity}

The chromatogram shown in fig. 2 represented the specificity of the developed method in efficiently separating the drug from its two impurities as seen from the RRT values and also thus satisfying the system suitability parameters. The method was further evaluated to check its specificity for the samples obtained after subjecting to various stress conditions as compared to the available method which is not a stability-indicating method [21]. The results of the forced degradation studies are reported in table 3.

\section{Acidic stress conditions}

The drug after subjecting to react with $1 \mathrm{~N} \mathrm{HCl}$ at $70{ }^{\circ} \mathrm{C}$ for $6 \mathrm{~h}$ showed no significant decrease in the peak area of the drug indicating its stability in acidic condition as shown in fig. 3 . The peaks seen at $\mathrm{R}_{\mathrm{t}}$ from 2 to 3 are due to blank samples treated with $\mathrm{HCl}$ at the detection wavelength. 


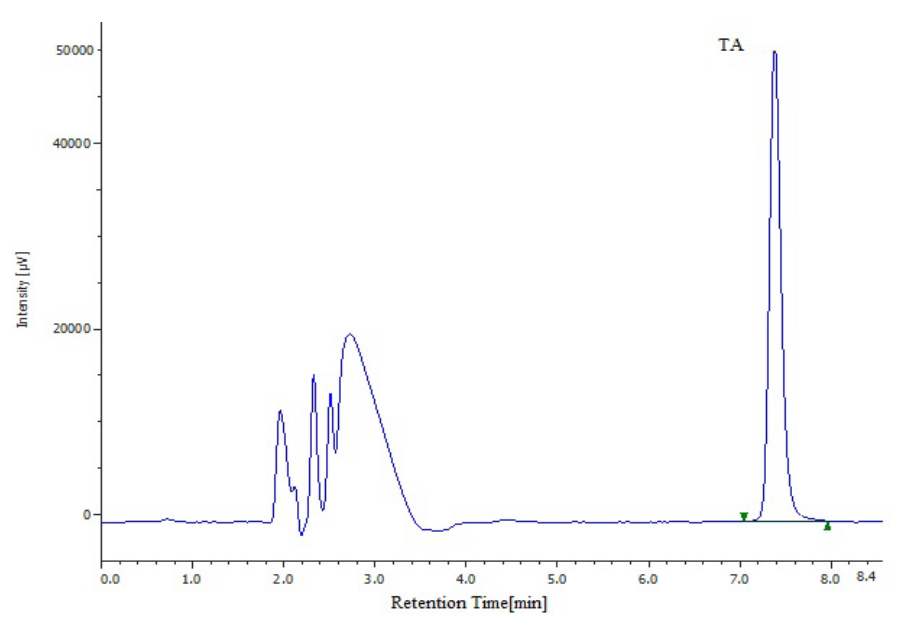

Fig. 2: Representative chromatogram of tolfenamic acid in acidic stress condition

\section{Basic stress condition}

Under the influence of $1 \mathrm{~N} \mathrm{NaOH}$ at $70^{\circ} \mathrm{C}$ for $6 \mathrm{~h}$ the drug didn't show any degradation, further highlighting its stability in the basic medium as shown by fig. 3 . The peaks seen at $R_{t}$ from 2 to 3 are due to blank samples treated with $\mathrm{NaOH}$ at the detection wavelength.

\section{Neutral stress condition}

When the drug was made to react with of water for $6 \mathrm{~h}$ at $70{ }^{\circ} \mathrm{C}$ it showed no degradation as shown by fig. 4 . Hence the drug was found to be stable in neutral medium.

\section{Thermal stress condition}

No degradation of the drug was seen when the drug was kept in oven at a temperature of $80^{\circ} \mathrm{C}$ for $96 \mathrm{~h}$ as confirmed by fig. 5 . Thus indicating its stability in thermal stress condition.

\section{Photolytic stress condition}

After exposure of the drug to direct sunlight for $4 \mathrm{~d}$ the samples showed no degradation of the drug, confirming its stability in the applied condition as per fig. 6 .

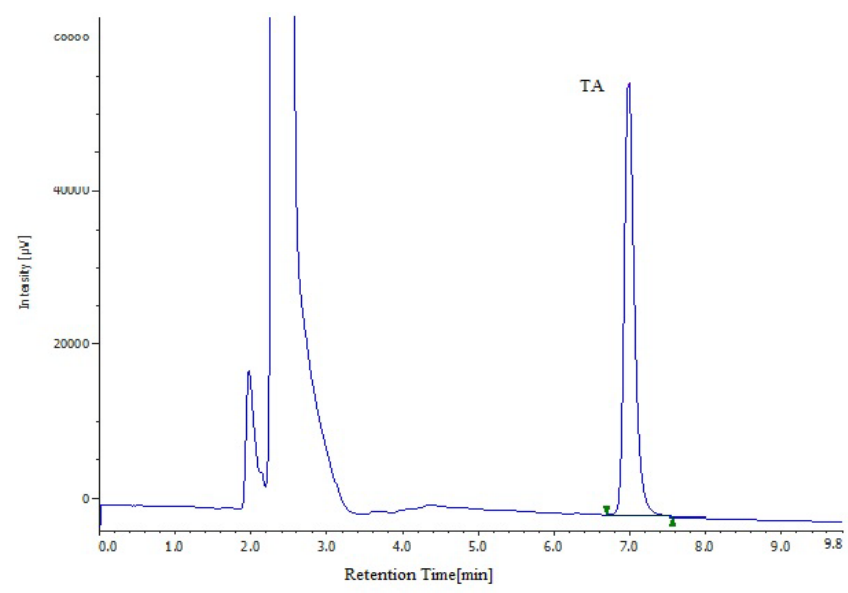

Fig. 3: Representative chromatogram of tolfenamic acid in basic stress condition

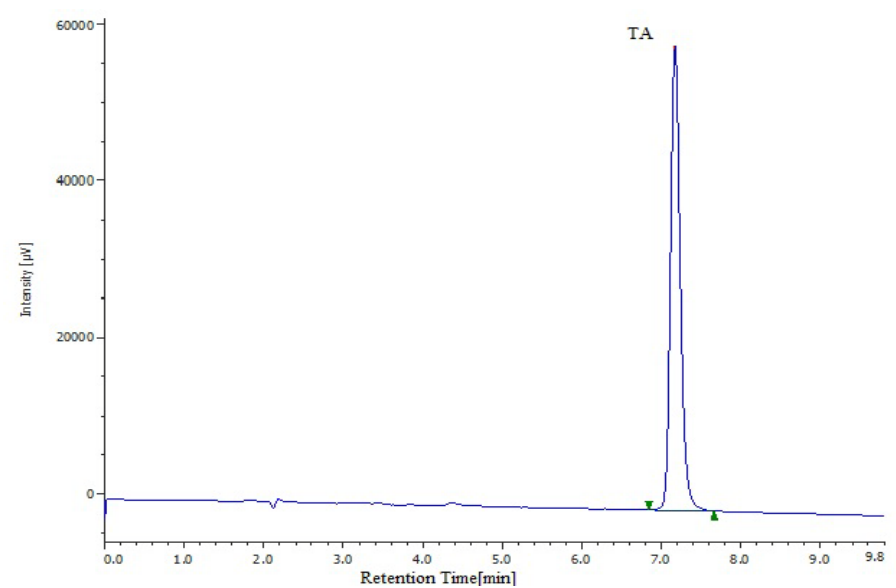

Fig. 4: Representative chromatogram of tolfenamic acid in neutral stress condition 


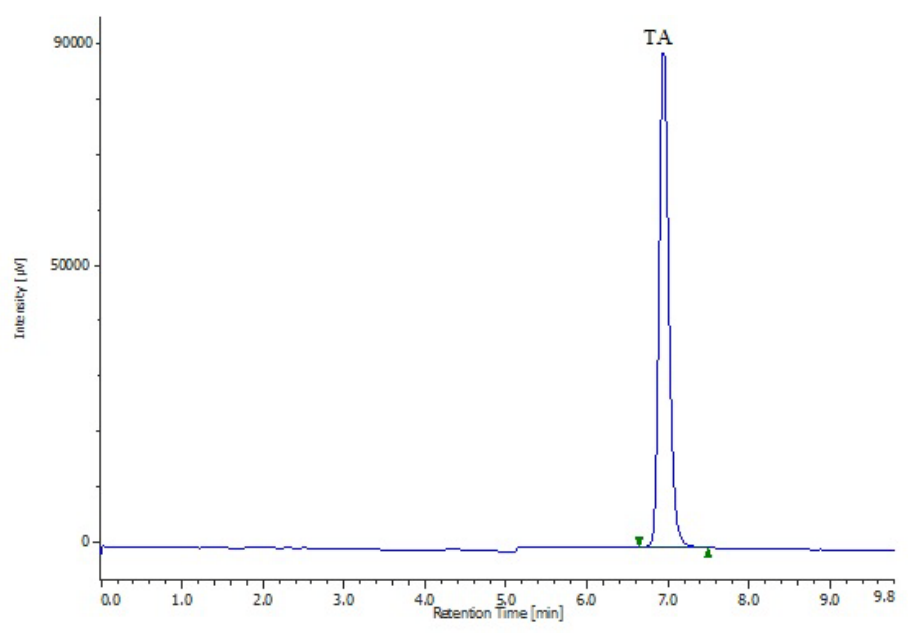

Fig. 5: Representative chromatogram of tolfenamic acid in thermal stress condition

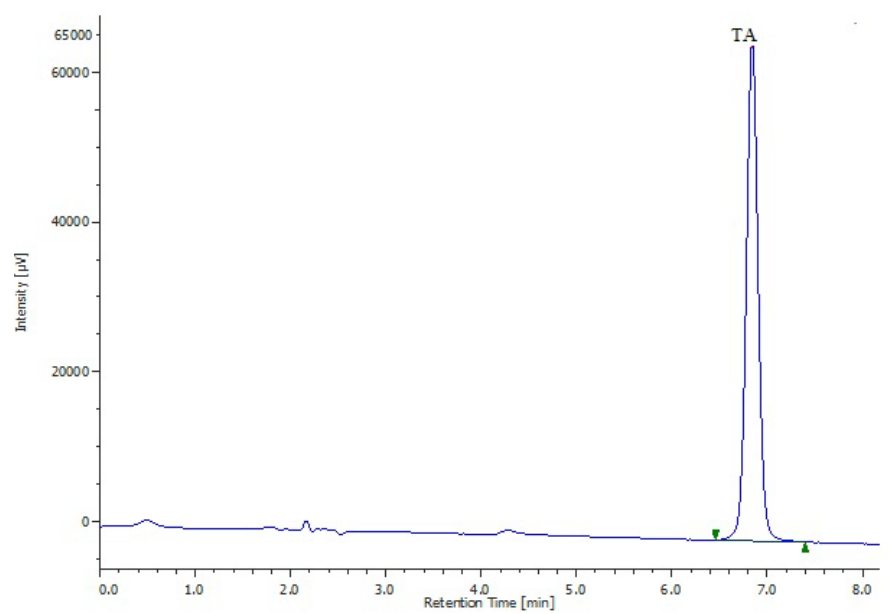

Fig. 6: Representative chromatogram of tolfenamic acid in photolytic stress condition

\section{Oxidative stress condition}

TA was found to be degraded in oxidative conditions, when treated with $10 \% \mathrm{H}_{2} \mathrm{O}_{2}$ after $2 \mathrm{~d}$. The obtained chromatogram on the sample (fig. 7) showed one peak of degradation product along with the peak of the drug. The RRT of the degradant formed is 0.54 which is different as compared to the RRT value of the two impurities with respect to the drug. Hence the formed degradant can be easily separated along with the two impurities highlighting the methods specificity. The peak at $R_{t}$ of 2.51 is due to the blank treated sample with $\mathrm{H}_{2} \mathrm{O}_{2}$ which is seen in all the samples subjected to oxidative stress condition.

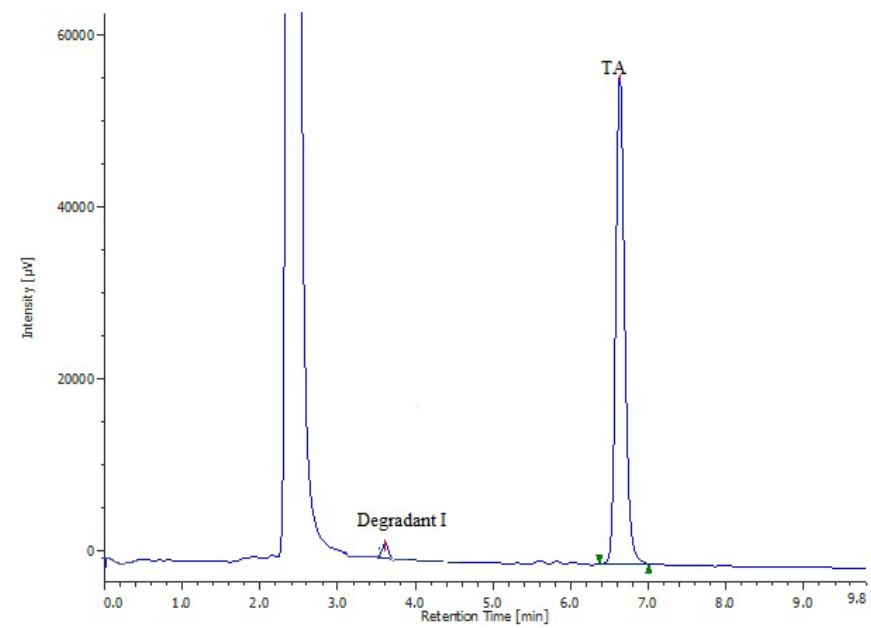

Fig. 7: Representative chromatogram of tolfenamic acid in oxidative stress condition 
Table 3: Forced degradation studies of tolfenamic acid $(n=2)$

\begin{tabular}{lll}
\hline Stress condition & Drug recovered (\%) & Drug decomposed (\%) \\
\hline Standard drug & 100 & - \\
Acidic hydrolysis & 90.50 & 9.5 \\
Alkaline hydrolysis & 90.50 & 9.5 \\
Neutral hydrolysis & 98.47 & 1.53 \\
Oxidative degradation & 85.61 & 14.39 \\
Thermal degradation & 92.93 & 7.07 \\
Photolytic degradation & 95.34 & 4.66 \\
\hline
\end{tabular}

$\mathrm{n}=$ number of determinations for each condition

\section{Linearity}

Standard calibration curves were obtained for TA and its two impurities i.e. CBA and CMA. The data showed linearity in the range of $10-100 \mu \mathrm{g} / \mathrm{ml}$ for TA and $0.1-1 \mu \mathrm{g} / \mathrm{ml}$ for CBA and CMA, with correlation coefficients of $\geq 0.995$ in all the cases which are within acceptable range i.e. more than 0.98 . Table 4 highlights the linearity parameters of the calibration curves for TA and its two impurities.

\section{Precision and sensitivity}

Intraday and intraday precision results obtained for the method are listed in the table 4. Percentage RSD values obtained for TA and the impurities were less than 2, which were within the acceptance criteria. Method sensitivity in terms of LOD and LOQ for TA and the impurities are as shown in table 4.

\section{Accuracy}

Satisfactory percentage recoveries of TA and the impurities were obtained at $80,100 \%$ and $120 \%$ of the test concentration. The accuracy results of the method were within the acceptable range of $95 \%$ to $105 \%$ as shown in table 5 .

\section{Robustness}

With deliberate changes in flow rate and in the proportion of organic phase in mobile phase, no significant changes in the system suitability parameters of the method for TA and for the impurities were seen as shown in table 6 . Thus the method was found to be robust.

Table 4: Regression parameters of the developed method

\begin{tabular}{llll}
\hline Parameters & Tolfenamic acid & Impurity A & Impurity B \\
\hline Range $(\mu \mathrm{g} / \mathrm{ml})$ & $10-100$ & $0.1-1$ & $0.1-1$ \\
Regression equation & $\mathrm{Y}=48849 \mathrm{x}+53707$ & $\mathrm{Y}=86129 \mathrm{x}+2217.4$ & \\
$\begin{array}{l}\text { Correlation coefficient } \\
\text { Intraday precision(n=3) }\end{array}$ & 0.9987 & 09984 & \\
Area $(\% \mathrm{RSD})$ & 0.81 & 0.44 & \\
Interday precision(n=3) & & & 0.9989 \\
Area(\%RSD) & 0.86 & 0.22 & 0.56 \\
$\mathrm{LOD}(\mu \mathrm{g} / \mathrm{ml})$ & 4.54 & 0.035 & 0.042 \\
$\mathrm{LOQ}(\mu \mathrm{g} / \mathrm{ml})$ & 13.77 & 0.106 & 0.128 \\
\hline
\end{tabular}

$\mathrm{n}=$ number of determinations

Table 5: Accuracy data of drug and its impurities (n=3)

\begin{tabular}{|c|c|c|c|c|c|c|}
\hline Component & $\begin{array}{l}\text { Amount of } \\
\text { sample } \\
(\mu \mathrm{g})\end{array}$ & $\begin{array}{l}\text { Level of } \\
\text { spiking } \\
(\%)\end{array}$ & $\begin{array}{l}\text { Amount of } \\
\text { spiked } \\
(\mu \mathrm{g})\end{array}$ & $\begin{array}{l}\text { Amount } \\
\text { recovered } \\
(\mu \mathrm{g})\end{array}$ & $\begin{array}{l}\text { \% recovery } \\
\pm \mathrm{SD}\end{array}$ & $\begin{array}{l}\% \\
\text { RSD } \\
\end{array}$ \\
\hline \multirow[t]{3}{*}{ Tolfenamic acid } & & 80 & 32 & 30.70 & $95.96 \pm 0.88$ & 0.91 \\
\hline & 40 & 100 & 40 & 40.20 & $99.99 \pm 1.6$ & 1.60 \\
\hline & & 120 & 48 & 47.09 & $98.11 \pm 0.78$ & 0.79 \\
\hline \multirow{3}{*}{ 2-chloro benzoic acid (Impurity A) } & & 80 & 0.32 & 0.31 & $96.82 \pm 1.34$ & 1.38 \\
\hline & 0.4 & 100 & 0.4 & 0.41 & $103.1 \pm 0.65$ & 0.63 \\
\hline & & 120 & 0.48 & 0.47 & $99.79 \pm 0.22$ & 0.22 \\
\hline \multirow[t]{3}{*}{ 3-Chloro 2-methylaniline (Impurity B) } & & 80 & 0.32 & 0.3204 & $100.12 \pm 0.70$ & 0.70 \\
\hline & 0.4 & 100 & 0.4 & 0.399 & $99.90 \pm 0.72$ & 0.72 \\
\hline & & 120 & 0.48 & 0.47 & $97.14 \pm 1.76$ & 1.81 \\
\hline
\end{tabular}

$\mathrm{n}=$ number of determinations, $\mathrm{SD}=$ Standard Deviation, $\% \mathrm{RSD}=\%$ Relative Standard Deviation

Table 6: Results of robustness studies $(n=3)$

\begin{tabular}{lll}
\hline Variable & Tolfenamic acid area (\%RSD) & Impurity A area (\%RSD) \\
\hline Change in flow rate & & \\
$0.8 \mathrm{ml} / \mathrm{min}$ & 0.35 & 0.39 \\
$1.2 \mathrm{ml} / \mathrm{min}$ & 0.77 & 1.21 \\
Change in composition of mobile phase & & \\
(ACN: Buffer) & & 1.77 \\
$78: 22 \mathrm{v} / \mathrm{v}$ & 0.81 & 0.71 \\
$82: 18 \mathrm{v} / \mathrm{v}$ & 0.35 & 0.71 \\
\hline
\end{tabular}

$\mathrm{n}=$ number of determinations, $(\%$ RSD $)=\%$ Relative Standard deviation 


\section{CONCLUSION}

A RP HPLC method was developed and validated as per ICH guidelines for estimation of TA in the presence of its two Pharmacopoeial impurities as well as degradation products. The method was found to be stability-indicating from the results obtained after application of the method to the stress samples of TA. The drug TA showed stability in acidic, basic, neutral, photo and thermal stress conditions and indicated degradation in oxidative stress conditions. The developed stability-indicating method is found to be simple, rapid, accurate, precise and robust as compared to other proposed methods while determining TA in presence of specified impurities and degradation products. Hence, the proposed method can be used for routine and stability sample analysis of TA.

\section{ACKNOWLEDGMENT}

The authors thank Government of Goa, Goa College of Pharmacy, Goa, India for providing necessary laboratory facilities to carry out the work. Thanks are also due to Pure and Cure Healthcare Pvt Ltd., Uttarakhand, for providing gift sample of Tolfenamic acid.

\section{AUTHORS CONTRIBUTIONS}

All the authors have contributed equally

\section{CONFLICT OF INTERESTS}

Declared none

\section{REFERENCES}

1. The Merck Index. In: Budawari S. editor. $13^{\text {th }}$ ed. Whitehouse Station, NJ: Merck and Co Inc; 2001.

2. British Pharmacopoeia. The department of Health. London. Stationary Office; 2009. p. 2244-5.

3. Martindale. The complete drug reference. In: Sweetman SC. editors. 34th ed. London: The Pharmaceutical Press; 2007.

4. Niopas I, Georgarakis M. Determination of tolfenamic acid in human plasma by HPLC. J Liq Chromatogr 1995;18:2675-82.

5. Colon J, Basha MR, Madero Visbal R, Kundari S, Baker $\mathrm{CH}$, Herrera LJ, et al. Tolfenamic acid decreases c-Met expression through Sp proteins degradation and inhibits lung cancer cells growth and tumor formation in orthotopic mice. Invest New Drugs 2011;29:41-51.

6. Eslin D, Sankpal UT, Lee C, Sutphin RM, Maliakal P, Currier E, et al. Tolfenamic acid inhibits neuroblastoma cell proliferation and induces apoptosis: a novel therapeutic agent for neuroblastoma. Mol Carcinog 2013;52:377-86.

7. Kim JH, Jung JY, Shim JH, Kim J, Choi KH, Shin JA, et al. Apoptotic effect of tolfenamic acid in KB human oral cancer cells: possible involvement of the p38 MAPK pathway. J Clin Biochem Nutr 2010;47:74-80.

8. Liu X, Abdelrahim M, Abudayyeh A, Lei P, Safe S. The nonsteroidal anti-inflammatory drug tolfenamic acid inhibits BT474 and SKBR3 breast cancer cell and tumor growth by repressing erbB2 expression. Mol Cancer Ther 2009;8:120717.

9. Babu C, Devanna N, Suresh R. Validated gradient stability indicating RP-HPLC method for the simultaneous quantification of 11 related substances in the combined dosage forms of lamivudine and tenofovir disopeoxil fumarate. Int $\mathrm{J}$ Appl Pharm 2017;9:61-8.

10. Shim JH, Shin JA, Jung JY, Choi KH, Choi ES, Cho NP. Chemopreventive effect of tolfenamic acid on KB human cervical cancer cells and tumor xenograft by downregulating specificity protein 1. Eur J Cancer Prev 2011;20:102-11.

11. Tsiliou S, Kefala LA, Perdih F, Turel I, Kessissoglou DP, Psomas G. Cobalt (II) complexes with non-steroidal anti-inflammatory drug tolfenamic acid: Structure and biological evaluation. Eur J Med Chem 2012;48:132-42.

12. Ioannou PC, Rusakova NV, Andrikopoulou DA, Glynou KM, Tzompanaki GM. Spectrofluorimetric determination of anthranilic acid derivatives based on terbium sensitized fluorescence. Analyst 1998;123:2839-43.

13. Papadoyannis I, Georgarakis M, Samanidou V, Zotou A. Rapid assay for the determination of tolfenamic acid in pharmaceutical preparations and biological fluids by highperformance liquid chromatography. J Liq Chromatogr Relat Technol 1991;14:2951-67.

14. Gallo P, Fabbrocino S, Dowling G, Salini M, Fiori M, Perretta G, et al. Confirmatory analysis of non-steroidal anti-inflammatory drugs in bovine milk by high-performance liquid chromatography with fluorescence detection. J Chromatogr A 2010;1217:2832-9.

15. Ibrahim H, Boyer A, Bouajila J, Couderc F, Nepveu F. Determination of non-steroidal anti-inflammatory drugs in pharmaceuticals and human serum by dual-mode gradient HPLC and fluorescence detection. J Chromatogr B 2007;857:59-6.

16. Gonzalez Barreiro C, Lores M, Casais MC, Cela R. Simultaneous determination of neutral and acidic pharmaceuticals in wastewater by high-performance liquid chromatography-postcolumn photochemically induced fluorimetry. J Chromatogr A 2003;993:29-37.

17. Mikami E, Goto $\mathrm{T}$, Ohno $\mathrm{T}$, Matsumoto $\mathrm{H}$, Inagaki $\mathrm{K}$, Ishihara $\mathrm{H}$, et al. Simultaneous analysis of anthranilic acid derivatives in pharmaceuticals and human urine by high-performance liquid chromatography with isocratic elution. J. Chromatogr B: Biomed Sci Appl 2000;744:81-9.

18. Rozou S, Antoniadou Vyza E. An improved HPLC method overcoming Beer's law deviations arising from supramolecular interactions in tolfenamic acid and cyclodextrins complexes. J Pharm Biomed Anal 1998;18:899-905.

19. Niopas I, Georgarakis M. Determination of tolfenamic acid in human plasma by HPLC. J Liq Chromatogr Relat Technol 1995;18:2675-82.

20. Papadoyannis IN, Zotou AC, Samanidou VF. Simultaneous reversed-phase gradient-HPLC analysis of anthranilic acid derivatives in anti-inflammatory drugs and samples of biological interest. Liq Chromatogr Relat Technol 1992;15:1923-45.

21. Shinozuka T, Takei S, Kuroda N, Kurihara K, Yanagida J. Micro determination of anthranilic acid derivatives of antiinflammatory drugs by high-performance liquid chromatography and its application to forensic chemistry. Eisei Kagaku 1991;37:461-6.

22. Abdelwahab NS, Ali NW, Zaki MM, Abdelkawy M. Validated chromatographic methods for simultaneous determination of tolfenamic acid and its major impurities. J Chromatogr Sci 2015;53:481-91.

23. International Conference on Harmonization (ICH), Stability testing of new drug substances and products, Q1A (R2); 2003.

24. International Conference on Harmonization (ICH) Harmonized Tripartite Guidelines, Validation of Analytical Procedures, Text, and Methodology, Q2 (R1), Parent Guidelines on Methodology Dated; 1996. p. 6 . 